\title{
Efektifitas Abu Sabut Kelapa dan Kapur Dalam Menstabilkan Tanah Lempung
}

\author{
Misbah $^{1}$, Juli Murdika Windi ${ }^{2}$ \\ Dosen Program Studi Teknik Sipil, Institut Teknologi Padang ${ }^{1,}$ Mahasiswa Program Studi Teknik \\ Sipil, Institut Teknologi Padang \\ DOI: http://dx.doi.org/10.31869/rtj.v3i2.1893
}

\begin{abstract}
Abstrak: Penelitian ini bertujuan untuk mengetahui pengaruh penambahan abu sabut kelapa dan kapur terhadap tanah lempung. Tanah yang diuji pada penelitian ini berasal dari Perumahan Taman Asri, desa Sungai Sapih, Kecamatan Kuranji, Kota Padang. Pencampuran tanah lempung dengan abu sabut kelapa dilakukan sebesar 0\%, 6\%, 9\%, 12\%, dan kapur 6\% terhadap berat kering tanah. Hasil penelitian menunjukkan pengujian saringan dan hidrometer tidak mengalami perubahan yang berarti. Untuk pengujian batas-batas konsistensi nilai batas cair dan indeks plastis menurun sebaliknya nilai batas plastis dan batas susut meningkat. Hasil uji pengembangan dan tekanan pengembangan nilai menurun. Untuk pemadatan hasil terbaik diperoleh pada pencampuran $6 \%$ abu sabut dan $6 \%$ kapur.
\end{abstract}

Kata Kunci : Tanah lempung, Abu sabut kelapa, Kapur, Sifat fisis dan Mekanis tanah lempung.

\section{PENDAHULUAN}

Jalan merupakan fasilitas transportasi yang paling sering digunakan oleh sebagian besar masyarakat, sehingga mempengaruhi aktivitas sehari-hari masyarakat. Kerusakan jalan yang terjadi diberbagai daerah saat ini merupakan permasalahan yang kompleks dan kerugian yang diderita sungguh besar terutama bagi para pengguna jalan, seperti waktu tempuh yang lama, terjadinya kemacetan lalu lintas, kecelakaan lalu lintas dan lain-lain. Faktor penyebab kerusakan jalan adalah kurang diperhatikan lapisan tanah pada dasar pondasi jalan itu sendiri. Material yang sangat penting dalam perencanaan Struktur Jalan adalah tanah, terutama sebagai dasar pondasi, sehingga mutlak diperlukan tanah yang memiliki kuat dukung tinggi dan penurunan sekecil mungkin. Oleh karena itu, diperlukan analisis kuat dukung tanah dan perancangan seksama agar tidak terjadi kegagalan stuktur jalan akibat runtuhnya tanah dasar pada pondasi dan berakibat rusaknya stuktur jalan diatasnya, karena pada tanah inilah suatu bidang jalan bertumpu, tetapi tidak semua jenis tanah yang ada memiliki kondisi yang baik untuk digunakan sebagai penumpu jalan, hal ini di sebabkan terdapat beberapa jenis tanah dasar yang bermasalah baik dari segi daya dukungnya maupun dari segi pengembangan (swelling) tanahnya. Disamping itu terdapat banyak karakteristik tanah yang dapat merugikan bagi pembangunan kontruksi jalan apabila tidak segera di tangani, misalnya jenis tanah lempung. Salah satu wilayah di Sumatra Barat khususnya kota Padang yang memiliki karakteristik tanah lempung yaitu di desa Sungai Sapih, Kecamatan Kuranji, Kota Padang. Sudah banyak penelitian yang dilakukan dalam memperbaiki sifat-sifat tanah lempung dengan mencampurkan bahan-bahan organik dan kimia. Pada kesempatan ini penulis menggunakan campuran serat sabut kelapa dan kapur dalam menstabilisasi tanah lempung, karena abu sabut kelapa dan kapur belum termanfaatkan secara optimal dalam menstabiliasi tanah lempung.

\section{TINJAUAN PUSTAKA}

Kadar air optimum tertinggi terdapat pada presentase campuran kapur $8 \%$ yaitu $=31,8 \%$, dan juga dapat dilihat bahwa penambahan kapur padam pada persentase $6 \%$ menghasilkan penurunan kohesi (Haras M, dkk 2017). Penambahan Kapur dan Abu Sekam padi dengan campuran $2 \%, 4 \%$, dan $6 \%$ dari berat kering tanah yang digunakan dapat menghasilkan nilai CBR yang lebih tinggi dari pada tanah yang dipadatkan pada kondisi OMC dan kondisi basah (Muntohar AS, 2016). Penggunaan fly ash dalam tanah lempung dapat menigkatkan nilai CBR tanah dasar dan meningkatkan klasifikasi tanah (Apriyanti A, 2014). Pencampuran Kapur sebanyak 3\% dan Spent Katalyst dengan variasi $1,5 \%, 3 \%, 4,5 \%$ yang di peram selama 7 hari dapat meningkatkan nilai UCS (Gunarti 
ASS, 2014). Sedangkan tanah lempung dicampur dengan abu limbah kertas menunjukan semakin tinggi persentase abu limbah kertas didalam kandungan tanah, nilainilai batas plastis, batas susut dan kepadatan tanah meningkat, sedangkan nilai-nilai batas cair, indeks plastisitas, pengembangan dan tekanan pengembangan cenderung menurun (Herman, Sari OP, 2018).

\section{LANDASAN TEORI}

Bahan yang digunakan sebagai stabilisasi yaitu:

\section{Abu Sabut Kelapa}

Abu sabut kelapa berasal dari pengolahan limbah sabut kelapa yang telah dibakar terlebih dahulu dengan menggunakan suhu tertentu sehingga menghasilkan abu. Abu sabut kelapa mengandung alumina, silika dan kalsium yang bersifat pozolan sehingga mempercepat waktu ikat semennya dikarenakan sifat pozolan tersebut dapat memperkecil pori-pori dalam pasta semen, mengisi rongga antar partikel. Komposisi senyawa dari abu sabut kelapa (dalam satuan persen berat) terdiri dari unsur $\mathrm{SiO} 2$ $=42,98 \%, \mathrm{Al} 2 \mathrm{O} 3=2,26 \%$, dan $\mathrm{Fe} 2 \mathrm{O} 3=$ $1,66 \%$. Pengelolaan abu sabut kelapa sangat mudah, cukup di bakar dengan panas tertentu hingga membentuk abu-abu, lalu disaring hingga mendapatkan abu yang benar-benar halus (Trikalina E, 2017).

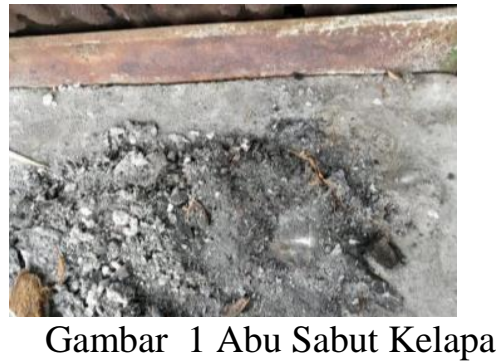

\section{Kapur}

Kapur dihasilkan dari pembakaran Kalsium Karbonat $(\mathrm{CaCO} 3)$ atau batu kapur alam (Natural Limestone) dengan pemanasan $980{ }^{\circ} \mathrm{C}$ karbon dioksidanya dilepaskan sehingga tinggal kapurnya saja $(\mathrm{CaO})$. Kalsium oksida yang diperoleh dari proses pembakaran tersebut dikenal dengan quick lime. Kapur dari hasil pembakaran bila ditambah air akan mengembang dan retakretak. Banyaknya panas yang keluar selama proses ini akan menghasilkan kalsium hidroksida $(\mathrm{Ca}(\mathrm{OH}) 2)$. Proses ini disebut slaking adapun hasilnya disebut slaked lime atau hydrated lime.

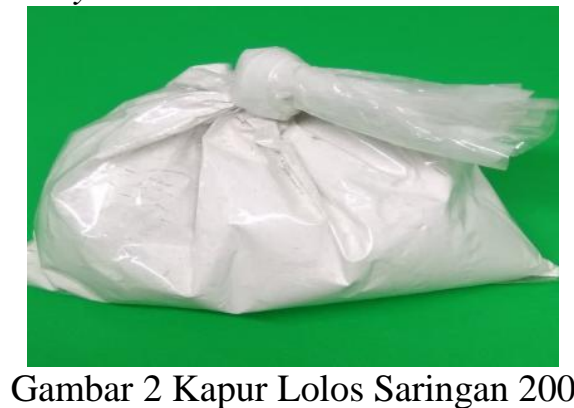

\section{METODE PENELITIAN}

Penelitian dilakukan di Laboratorium Teknik Sipil Institut Teknologi Padang. Sampel tanah berasal dari desa Sungai Sapih, Kecamatan Kuranji, Kota Padang, pada kedalaman 20 - 30 $\mathrm{cm}$ dari muka tanah dan kapur diambil dari ex toko bangunan HAPDI. Abu sabut kelapa diambil dari limbah pembakaran Kue Bika di Jln Raya Tepi Bandar, Batang Kapas, Pesisir Selatan. Pencampuran Abu Sabut Kelapa adalah $0 \%, 6 \%, 9 \%, 12 \%$ dan kapur 6\% terhadap berat kering tanah.

\section{Prosedur Penelitian}

a. Penelitian Pendahuluan

Penelitian pendahuluan ini terdiri dari uji sifat fisis dan sifat mekanis tanah yang terdiri

1. Pengujian kadar air, prosedur pengujian mengacu pada ASTM D2216.

2. Pengujian specific gravity, prosedur pengujian mengacu pada ASTM D854

3. Pengujian distribusi ukuran butiran tanah, prosedur pengujian mengacu pada ASTM D421 Dan D422

4. Pengujian batas konsistensi, prosedur pengujian mengacu pada ASTM D4318

5. Pengujian pemadatan, prosedur pengujian mengacu pada ASTM D698

6. Pengujian pengembangan dan tekanan pengembangan, prosedur pengujian mengacu pada ASTM D4546

\section{b. Penelitian Utama}

Penelitian utama terdiri dari uji sifat fisis dan mekanis tanah yang telah dicampur dengan abu sabut kelapa dan kapur. Untuk lebih jelas prosedur penelitian dapat dilihat 
pada bagan alir penelitian (Gambar 3) dibawah ini :

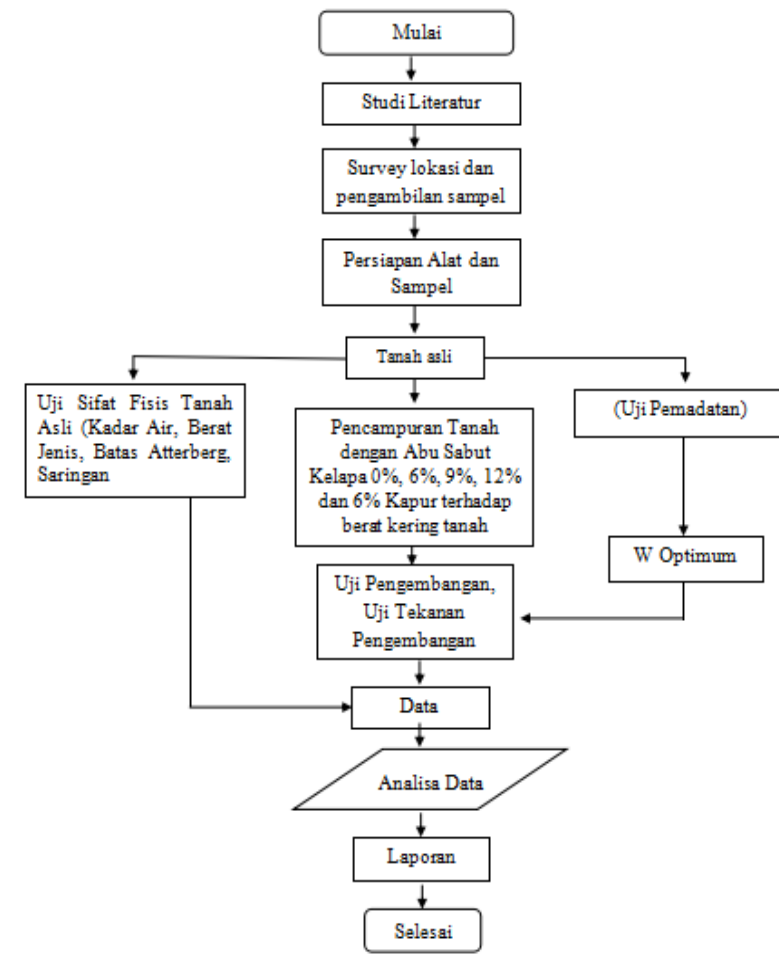

Gambar 3 Aliran Penelitian

\section{HASIL DAN PEMBAHASAN}

\section{Hasil Penelitian Pendahuluan}

Hasil pemeriksaan uji sifat tanah asli, abu sabut kelapa, kapur dan uji sifat mekanis tanah asli tercantum pada: Tabel 1, Tabel 2, Tabel 3, Tabel 4.

Tabel 1 Hasil Pengujian Sifat Fisis Tanah Asli

Sumber: Data Hasil Penelitian 2019

Tabel 2 Hasil Pengujian Berat Jenis kapur

\begin{tabular}{|c|l|c|}
\hline No & \multicolumn{1}{|c|}{ Jenis Penelitian } & Hasil \\
\hline 1 & $\begin{array}{l}\text { Berat jenis (Specific gravity, } \\
\text { Gs) }\end{array}$ & 2.45 \\
\hline
\end{tabular}

Sumber: Data Hasil Penelitian 2019

Tabel 3 Hasil Pengujian Berat Jenis Abu Sabut Kelapa

\begin{tabular}{|c|l|c|}
\hline No & \multicolumn{1}{|c|}{ Jenis Penelitian } & Hasil \\
\hline 1 & $\begin{array}{l}\text { Berat jenis (Specific gravity, } \\
\text { Gs })\end{array}$ & 2.24 \\
\hline
\end{tabular}

Sumber: Data Hasil Penelitian 2019
Tabel 4 Hasil Pengujian Sifat Mekanis Tanah Asli

\begin{tabular}{|c|l|c|}
\hline No. & \multicolumn{1}{|c|}{ Jenis Penelitian } & Hasil \\
\hline 1 & $\begin{array}{l}\text { Berat jenis (Specific gravity, } \\
\text { Gs) }\end{array}$ & 2.56 \\
\hline 2 & Batas cair (Liquid limit, LL) & $72.16 \%$ \\
\hline 3 & $\begin{array}{l}\text { Batas plastis (Plastic limit, } \\
P L \text { ) }\end{array}$ & $48.10 \%$ \\
\hline \multirow{2}{*}{4} & $\begin{array}{l}\text { Batas susut (Shrinkage limit, } \\
\text { SL) }\end{array}$ & $34.66 \%$ \\
\hline 5 & Plasticity indeks (PI) & $24.07 \%$ \\
\hline 6 & Uji saringan dan hydrometer & \\
\hline \multirow{6}{*}{} & - Lolos saringan No 200 & $93.71 \%$ \\
\cline { 2 - 3 } & - Tertahan saringan No 200 & $6,29 \%$ \\
\cline { 2 - 3 } & D10 & $\begin{array}{c}0.010 \\
\mathrm{~mm}\end{array}$ \\
\cline { 2 - 3 } & \multirow{2}{*}{ D30 } & $\begin{array}{c}0.038 \\
\mathrm{~mm}\end{array}$ \\
\cline { 2 - 3 } & \multirow{2}{*}{ D60 } & $\begin{array}{c}0.059 \\
\mathrm{~mm}\end{array}$ \\
\cline { 2 - 3 } & Cu & 3.19 \\
\cline { 2 - 3 } & Cc & 1.77 \\
\cline { 2 - 3 } & Gradasi Tanah & Buruk \\
\hline
\end{tabular}

Sumber: Data Hasil Penelitian 2019

\section{Hasil Penelitian Utama}

Hasil pemeriksaan uji sifat fisis dan mekanis tanah yang telah dicampur dengan abu sabut kelapa dan kapur, tercantum pada : Tabel 5 dan Tabel 6.

Tabel 5 Hasil Uji Sifat Fisis tanah yang di beri campuran abu sabut kelapa dan kapur.

\begin{tabular}{|c|l|c|}
\hline No & \multicolumn{1}{|c|}{ Jenis Penelitian } & Hasil \\
\hline \multirow{2}{*}{1} & Berat volume kering & 1.182 \\
& maksimum $(\gamma \mathrm{d})$ maks & $\mathrm{g} / \mathrm{cm} 3$ \\
\hline 2 & Kadar air optimum $\left(\mathrm{W}_{\text {opt }}\right)$ & $39 \%$ \\
\hline 3 & Persen Pengembangan & $0.59 \%$ \\
\hline 4 & Tekanan pengembangan & $155 \mathrm{kPa}$ \\
\hline
\end{tabular}

Sumber: Data Hasil Penelitian 2019 
$=(31,99)$ dibulatkan menjadi 32

Tabel 6 Hasil Pengujian Sifat Mekanis

Campuran Tanah, abu sabut kelapa, dan kapur.

\begin{tabular}{|c|c|c|c|c|}
\hline \multirow[b]{2}{*}{ No } & \multirow[b]{2}{*}{$\begin{array}{c}\text { Jenis } \\
\text { Penelitian }\end{array}$} & \multicolumn{3}{|c|}{ Hasil } \\
\hline & & $\begin{array}{c}\text { T. } \\
\text { Asli }\end{array}$ & $\begin{array}{c}\text { T. } \\
\text { Asli + } \\
\text { abu } \\
6 \%+ \\
\text { kapu } \\
\text { r } 6 \%\end{array}$ & $\begin{array}{r}\text { T } \\
\text { Asl } \\
\text { ab } \\
9 \% \\
\text { ka } \\
\text { r } 6\end{array}$ \\
\hline 1 & $\begin{array}{l}\text { Berat volume } \\
\text { kering } \\
\text { maksimum }(\gamma \mathrm{d}) \\
\text { maks }\end{array}$ & $\begin{array}{l}1.1 \\
82 / \\
\mathrm{cm}^{3}\end{array}$ & $\begin{array}{l}1.22 \mathrm{~g} / \\
\mathrm{cm}^{3}\end{array}$ & 1.19 \\
\hline 2 & $\begin{array}{l}\text { Kadar air } \\
\text { optimum }\left(\mathrm{W}_{\mathrm{opt}}\right)\end{array}$ & $\begin{array}{l}39 . \\
00 \\
\%\end{array}$ & $\begin{array}{c}20.25 \\
\%\end{array}$ & \\
\hline 3 & Pengembangan & $\begin{array}{c}0.5 \\
9\end{array}$ & 0.01 & 0.0 \\
\hline 4 & $\begin{array}{l}\text { Tekanan } \\
\text { pengembangan }\end{array}$ & $\begin{array}{l}155 \\
\mathrm{kPa}\end{array}$ & $\begin{array}{c}49 \\
\mathrm{kPa}\end{array}$ & $47 k$ \\
\hline
\end{tabular}

Sumber: Data Hasil Penelitian 2019

\section{PEMBAHASAN}

\section{Tanah Asli}

Hasil penelitian nilai persentase lolos saringan no. 200 sebesar $93,71 \%>50 \%$, maka tanah termasuk jenis tanah berbutir halus, nilai batas cair Liquid Limit (LL) adalah $72,16 \%>50 \%$ menunjukan bahwa tanah termasuk tanah berbutir halus, dan jika dilihat dari harga Plasticity index, (PI) adalah $24,07 \%$, jika nilainilai ini diplot pada kurva plastisitas jatuh pada MH berarti tanah adalah lanau tak organik dengan plastisitas tinggi (Unified Soil Clasification System atau USCS).

Menurut AASHTO persentase lolos saringan no. 200 sebesar $93,71 \%>35 \%$, maka tanah termasuk jenis tanah lanau atau lempung, nilai batas cair $(L L)$ adalah $72,16 \%>41 \%$ menunjukkan bahwa tanah termasuk A-5, A-7, dari nilai Plasticity index, (PI) adalah $24,07 \%$ $>11 \%$ maka tanah termasuk A-7, berdasarkan Plastic Limit, $(P L)$ adalah 48,10 > 30\% maka tanah termasuk A-7-5, (ASSHTO)

$$
\begin{aligned}
G I= & (93,10-35)[0,2+0,005(72,16- \\
& 40)]+0,01 \quad(93,71-15)(24,07- \\
& 10) \\
& =(58,1)(0,36)+(0,01)(78,71) \\
& =(20,92)+(11,07)
\end{aligned}
$$

\begin{tabular}{|c|c|c|c|c|c|}
\hline \multirow[b]{2}{*}{ No } & \multirow[b]{2}{*}{ Jenis Penelitian } & \multicolumn{4}{|c|}{ Hasil } \\
\hline & & $\begin{array}{l}\text { T. } \\
\text { Asli }\end{array}$ & $\begin{array}{c}\text { T. } \\
\text { Asli + } \\
\text { abu } \\
6 \%+ \\
\text { kapur } \\
6 \%\end{array}$ & $\begin{array}{c}\text { T. } \\
\text { Asli + } \\
\text { abu } \\
9 \%+ \\
\text { kapur } \\
6 \%\end{array}$ & $\begin{array}{c}\text { T. } \\
\text { Asli } \\
+ \\
\text { abu } \\
12 \% \\
+ \\
\text { kapu } \\
\text { r 6\% }\end{array}$ \\
\hline $\begin{array}{l}1.16 \\
\$ / \mathrm{cm}^{3}\end{array}$ & $\begin{array}{l}\text { Berat jenis } \\
\text { Specific gravity, } \\
\text { Gs) }\end{array}$ & 2.56 & 2.53 & 2.53 & 2.51 \\
\hline $\begin{array}{c}37.49 \\
\%\end{array}$ & $\begin{array}{l}\text { Batas cair } \\
\text { Liquid limit, } \\
\text { LL) }\end{array}$ & $\begin{array}{c}72.16 \\
\%\end{array}$ & $\begin{array}{c}70.77 \\
\%\end{array}$ & $\begin{array}{c}68.05 \\
\%\end{array}$ & $\begin{array}{c}66.43 \\
\%\end{array}$ \\
\hline $0, \hat{\theta} 2$ & $\begin{array}{l}\text { Batas plastis } \\
\text { Plastic limit, } \\
\text { PL) }\end{array}$ & $\begin{array}{c}48.10 \\
\%\end{array}$ & $\begin{array}{c}51.48 \\
\%\end{array}$ & $\begin{array}{c}53.44 \\
\%\end{array}$ & $\begin{array}{c}57.20 \\
\%\end{array}$ \\
\hline $47 \mathrm{kPa}$ & $\begin{array}{l}\text { Batas susut } \\
\text { Shrinkage limit, } \\
\text { SL) }\end{array}$ & $\begin{array}{c}34.66 \\
\%\end{array}$ & $\begin{array}{c}42.05 \\
\%\end{array}$ & $\begin{array}{c}43.07 \\
\%\end{array}$ & $\begin{array}{c}43.64 \\
\%\end{array}$ \\
\hline 5 & $\begin{array}{l}\text { Plasticity indeks } \\
(P I)\end{array}$ & $\begin{array}{c}24.07 \\
\%\end{array}$ & $\begin{array}{c}19.29 \\
\%\end{array}$ & $\begin{array}{c}14.61 \\
\%\end{array}$ & $\begin{array}{c}9.23 \\
\%\end{array}$ \\
\hline 6 & $\begin{array}{l}\text { Uji saringan dan } \\
\text { hydrometer }\end{array}$ & & & & \\
\hline & $\begin{array}{l}\text { - Lolos saringan } \\
\text { No } 200\end{array}$ & $\begin{array}{c}93.71 \\
\%\end{array}$ & $\begin{array}{c}94.61 \\
\%\end{array}$ & $\begin{array}{c}92.57 \\
\%\end{array}$ & $\begin{array}{c}93.08 \\
\%\end{array}$ \\
\hline & $\begin{array}{l}\text { - Tertahan } \\
\text { saringan No } 200\end{array}$ & 6.29 & 5.16 & 7.43 & 6.92 \\
\hline & D10 & 0.010 & $\begin{array}{c}0.007 \\
0\end{array}$ & $\begin{array}{c}0.002 \\
3\end{array}$ & $\begin{array}{c}0.002 \\
3\end{array}$ \\
\hline & D30 & 0.038 & 0.011 & 0.006 & 0.009 \\
\hline & D60 & 0.059 & 0.03 & 0.04 & 0.045 \\
\hline & $\mathrm{Cu}$ & 3.19 & 4.29 & 17.39 & 19.57 \\
\hline & $\mathrm{Cc}$ & 1.77 & 0.58 & 0.39 & 0.78 \\
\hline & Gradasi Tanah & $\begin{array}{c}\text { Buru } \\
\mathrm{k}\end{array}$ & Buruk & Buruk & $\begin{array}{c}\text { Buru } \\
\mathrm{k}\end{array}$ \\
\hline
\end{tabular}

Dilihat dari hasil nilai $G I$, dapat disimpulkan bahwa tanah ini masuk dalam kelompok pada A-7-5 (32) yaitu kelompok tanah buruk (tidak baik) jika dimanfaatkan sebagai tanah dasar pada pekerjaan jalan.

\section{Tanah Yang Telah dicampur Abu Sabut Kelapa dan Kapur}

Pencampuran Abu Sabut Kelapa dan Kapur terhadap tanah asli dapat merubah sifat fisis dan sifat mekanis tanah asli. Hasil uji tanah yang telah di campur dengan $6 \%$ kapur dan 
yang telah di tambah dengan berbagai variasi abu sabut kelapa seperti hasil di bawah ini:

\section{a. Butiran lolos saringan no. 200}

Dari hasil pengujian saringan dan hidrometer menunjukan kurva cenderung mendatar, artinya kapur dan abu tidak menunjukan perubahan yang signifikan, hal ini disebabkan oleh karena masa perawatan yang singkat (3 hari) tidak cukup bagi kapur untuk mengikat butiran tanah. Pada pencampuran $6 \%$ abu sabut kelapa dan $6 \%$ kapur nilai persen lolos saringan no. 200 adalah $94.61 \%$ sedangkan nilai persen lolos saringan no. 200 tanah asli adalah $93.71 \%$, terjadi kenaikan 0.9 atau $0.96 \%$ dari nilai lolos saringan no. 200 tanah asli. Pada peningkatam abu selanjutnya nilai ini cenderung menurun, pada percampuran tanah dengan abu sabut kelapa $12 \%$ dan $6 \%$ kapur, nilai persen lolos saringan 200 ialah 93.08\% jika dibandingkan dengan persen lolos saringan no. 200 tanah asli 93.71\% terjadi penurunan 0.63 atau $0.67 \%$ dari lolos saringan no. 200 tanah asli. Hal ini terjadi ikatan antara butiran tanah, abu sabut kelapa dan kapur, tetapi pada \% abu yang sedikit hal ini belum terlihat.

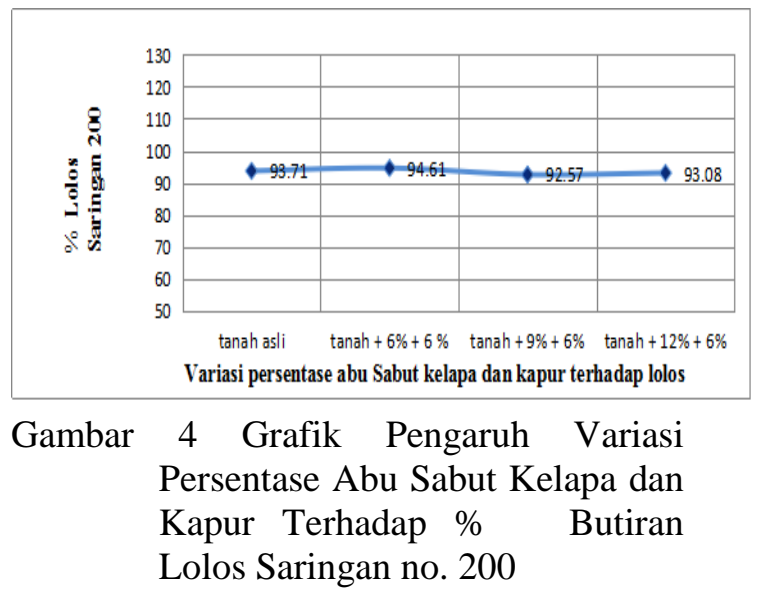

\section{b. Berat Jenis (Specific Gravity ( Gs )}

Hasil uji Specific Gravity ( $G s$ ) tanah asli dengan tanah yang telah dicampur dengan variasi persentase kapur tercantum pada Tabel 1, Tabel 2, Tabel 5 dan Gambar 5.

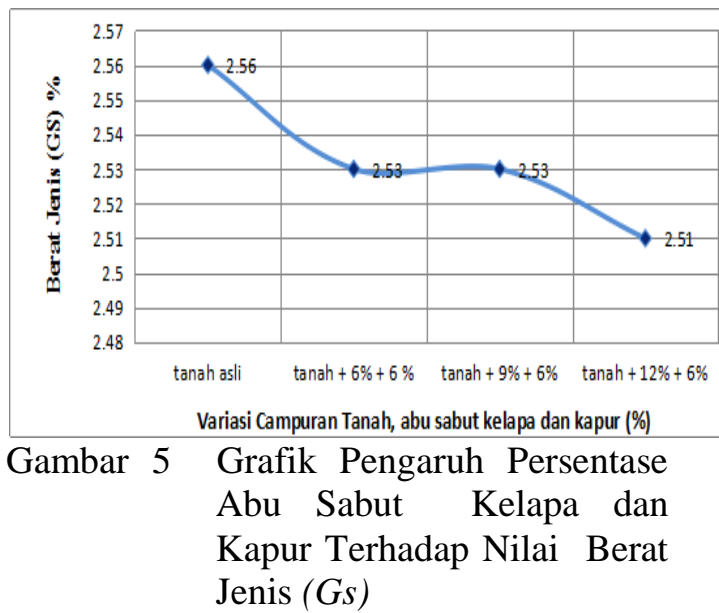

Pada kurva pencampuran tanah, kapur, dan abu sabut kelapa nilai berat jenis (Gs) cenderung menurun. Hasil pencampuran tanah dengan $12 \%$ abu sabut kelapa dan $6 \%$ kapur nilai berat jenisnya adalah $2.51 \%$. Jika dibandingkan dengan nilai berat jenis (Gs) tanah asli nilainya adalah $2.56 \%$, terjadi penurunan 0.05 atau $1.95 \%$ dari nilai berat jenis tanah asli. Penurunan ini disebabkan karena berat jenis (Gs) abu sabut kelapa dan kapur lebih rendah dari tanah asli, sehingga berat jenis tanah dicampur abu sabut kelapa dan kapur menjadi menurun.

\section{c. Batas - batas Attereberg}

Hasil pengujian batas-batas konsistensi tanah asli dan tanah yang sudah dicampur dengan berbagi variasi persentase abu sabut kelapa dan $6 \%$ kapur, seperti terlihat pada Tabel 1, Tabel 3 dan Gambar 6 berikut ini

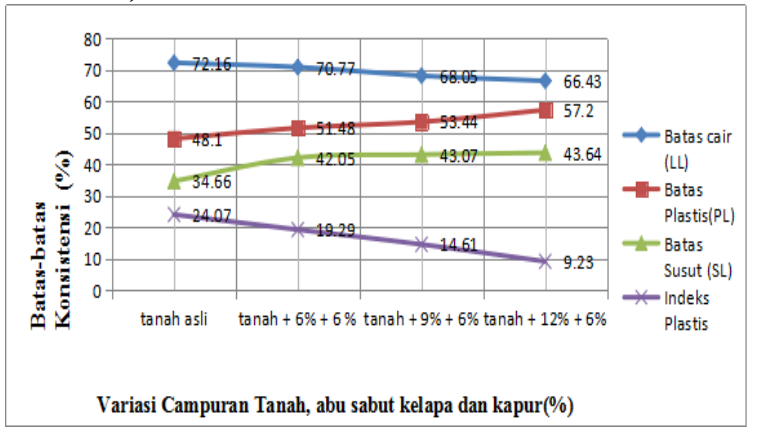

\section{Gambar 6 Grafik Nilai Batas-Batas Attereberg Pencampuran Abu Sabut Kelapa dan Kapur}

Kurva menunjukan bahwa persentase variasi abu sabut kelapa dan kapur dalam campuran tanah mengindikasikan perubahan nilai-nilai Batas Cair $(L L)$, Batas 
Plastis $(P L)$, Batas Susut $(S L)$ dan Indeks Plastisitas $(P I)$. Pada pencampuran tanah dengan variasi abu sabut kelapa dan kapur nilai Batas Cair $(L L)$ cenderung menurun. Pencampuran tanah dengan $12 \%$ abu sabut kelapa dan $6 \%$ kapur nilai batas cairnya adalah $66.43 \%$, jika nilai ini dibandingkan dengan nilai Batas Cair ( $L L)$ tanah asli nilainya $72,16 \%$ terjadi penurunan 5.73 atau $7.94 \%$ terhadap nilai batas cair tanah asli. Hal ini di sebabkan karena abu sabut kelapa dan kapur menghalangi ikatan antar butiran melalui ikatan ion, sehinggga ikatan butiran menjadi lemah.

Kurva juga menunjukkan pencampuran tanah dengan berbagai variasi persen abu sabut kelapa dan 6\% kapur nilai Batas Plastis $(P L)$ terjadi kenaikan. Pada pencampuran tanah $12 \%$ abu sabut kelapa dan 6\% kapur nilai Batas Plastisnya adalah $57,20 \%$. Jika di bandingkan dengan nilai Batas Plastis $(P L)$ tanah asli nilainya $48,10 \%$ terjadi kenaikan $9.1 \%$ atau $18.91 \%$ terhadap nilai batas plastis tanah asli. Hal ini disebabkan karena menurunnya plastisitas tanah sehingga tanah lebih banyak membutuhkan air untuk mempertahankan plastisitasnya. Nilai Plasticity Indeks (PI) cenderung menurun. Pencampuran tanah dengan $12 \%$ abu sabut kelapa dan 6\% kapur nilai Indeks Plastisnya adalah $9.23 \%$ Jika di bandingkan dengan nilai Indeks Plastis (PI) tanah asli nilainya $24.07 \%$ terjadi penurunan 14.84 atau $61 \%$ terhadap nilai indeks plastis tanah asli. Hal ini di sebabkan karena indeks plastisitas mengikuti besaran batas cair dan batas plastis. Nilai Batas Susut (SL) cenderung meningkat. pada pencampuran tanah $12 \%$ abu sabut kelapa dan 6\% kapur nilai Batas Susutnya adalah $43.64 \%$. Jika di bandingkan dengan nilai Batas Susut (SL) tanah asli nilainya $34.66 \%$ terjadi kenaikan 8.98 atau $25.90 \%$ terhadap nilai batas susut tanah asli. Hal ini disebabkan oleh penambahan abu sabut kelapa dan kapur, butiran semakin kasar (dapat di lihat dari uji saringan), semakin kasar butiran penyusutannya semakin kecil, hal ini mengindikasikan batas susutnya meningkat.

\section{d. Pemadatan (Compaction)}

Hasil uji pemadatan standar dari tanah asli dan tanah yang telah dicampur abu sabut kelapa dan kapur dengan beberapa variasi persentase, tercantum pada Tabel 2, Tabel 4 dan Gambar 7, Gambar 8.

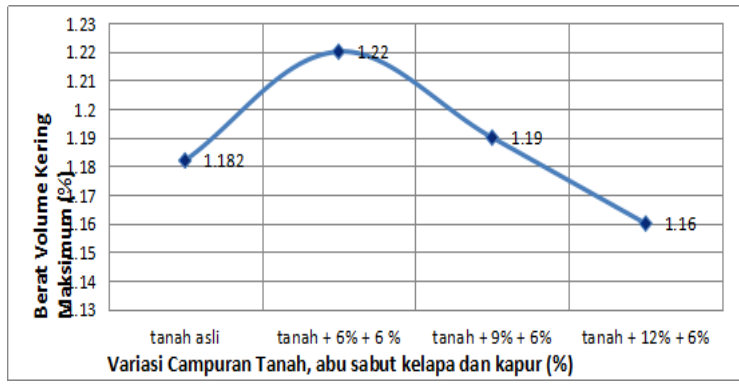

Gambar 7 Grafik Pengaruh Persentase Abu Sabut Kelapa dan Kapur Terhadap Nilai Berat Volume Kering Maksimum $(M D D)$

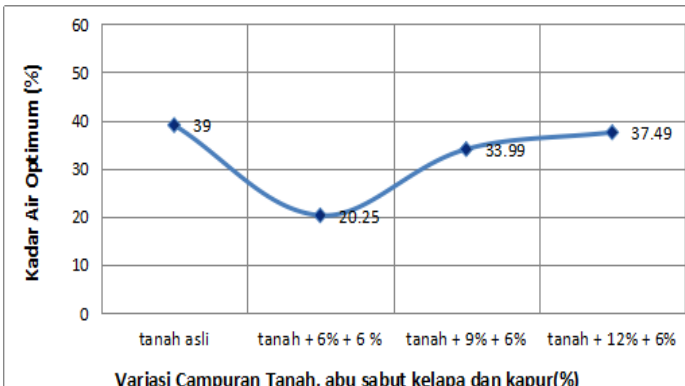

Gambar 8 Grafik Pengaruh Persentase Abu Sabut

Kelapa dan Kapur

Terhadap Nilai

Kadar Air Optimum (OMC)

Dari hasil uji pemadatan ini menunjukkan bahwa penambahan persentase abu sabut kelapa dan kapur pada tanah memperlihatkan adanya perubahan nilai dari berat volume kering maksimum $(M D D)$ dan nilai kadar air optimum (OMC). Pada persentase 6\% abu sabut kelapa dan $6 \%$ kapur nilai berat volume kering maksimumnya $(M D D) 1.22 \mathrm{gr} / \mathrm{cm}^{3}$, jika dibandingkan dengan nilai berat volume kering maksimum (MDD) tanah asli yaitu sebesar $1.182 \mathrm{gr} / \mathrm{cm}^{3}$, terjadi peningkatan sebesar $0,038 \mathrm{gr} / \mathrm{cm}^{3}$ atau $3.21 \%$ dari berat volume kering maksimum tanah asli. Sebaliknya, nilai kadar air optimumnya (OMC) menurun, pada persentase abu sabut kelapa $6 \%$ dan kapur 6\% mengalami penurunan dengan nilai 
kadar air optimum $(O M C) 20.25 \%$, Nilai ini jika dibandingkan dengan nilai kadar air optimum $(O M C)$ tanah asli yaitu sebesar $39 \%$, terjadi penurunan sebesar 18.75 atau $48.07 \%$ dari nilai kadar air optimum tanah asli. Hal ini disebabkan karena abu sabut kelapa dan kapur mengisi rongga pori disaat pemadatan sehingga pemadatan meningkat, mengecilnya rongga pori mengakibatkan sebagian air keluar meninggalkan rongga, keluarnya air pori mengidentifikasikan kadar air optimum menurun.

Pada penambahan abu selanjutnya kadar air optimum meningkat, akibatnya rongga yang tadinya terisi butiran halus digantikan dengan air, sehingga rongga membesar dan akibatnya kepadatan menurun.

e. Pengembangan dan Tekanan Pengembangan

Hasil uji Pengembangan dan Tekanan pengembangan dari tanah asli dan tanah yang telah dicampur variasi abu sabut kelapa dan 6\% kapur, tercantum pada Tabel 2, Tabel 4 dan Gambar 9, Gambar 10.

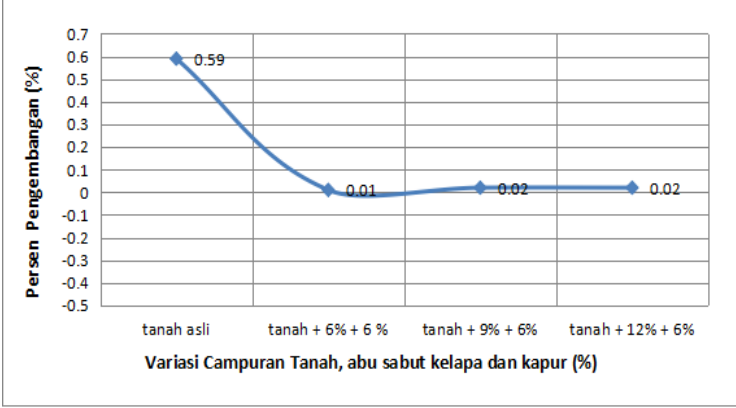

Gambar 9 Pengaruh Abu Sabut Kelapa dan Kapur Terhadap Persen Pengembangan Tanah

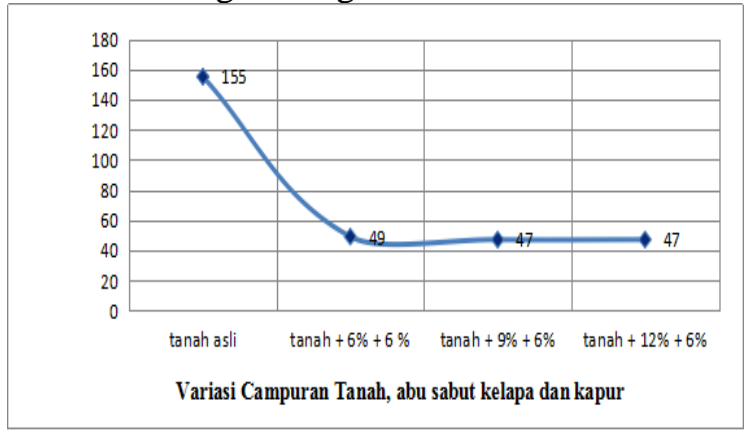

Gambar 10 Pengaruh Abu Sabut Kelapa dan Kapur Terhadap Tekanan

Pengembangan Tanah
Pada kurva terlihat nilai pengembangan dan tekanan pengembangan cenderung menurun, seiring dengan meningkatnya persentase abu sabut kelapa didalam tanah nilai itu sama, hasil uji pengembangan menunjukkan pada tanah asli terjadi pengembangan sebesar $0,59 \%$, dan pada penambahan $12 \%$ abu sabut kelapa dan $6 \%$ kapur yaitu sebesar $0.02 \%$ jika dibandingkan dengan nilai pengembangan tanah asli adalah 0,59\% terjadi penurunan 0.57 atau 96,61\%. Dari nilai tekanan pengembangan pada pencampuran variasi abu sabut kelapa dan 6\% kapur nilainya cenderung menurun, pada pencampuran $12 \%$ abu sabut kelapa dan $6 \%$ kapur nilai tekanan pengembangannya adalah $47 \mathrm{kpa}$ jika dibandingkan dengan tekanan pengembangan tanah asli adalah $155 \mathrm{kpa}$ terjadi penurunan sebesar $108 \mathrm{kpa}$ atau $69,67 \%$. Hal ini disebabkan karena menurunnya plastisitas tanah.

Dari hasil analisa diatas diperoleh kondisi yang terbaik pada pencampuran $6 \%$ abu sabut kelapa dan 6\% kapur terhadap tanah. dimana tanah masih MH (USCS) atau A-75 (28) AASHTO, tetapi stabiltas tanah sudah meningkat dengan menurunnya nilai pengembangan dan tekanan pengembangan tanah.

\section{PENUTUP}

Simpulan

Dari hasil penelitan dan analisa penulis, secara umum dapat disimpulkan beberapa hal, yaitu :

1. Menurut kedua klasifikasi tanah yaitu USCS dan AASHTO, tanah yang di uji masuk dalam kategori tanah MH yaitu tanah Anorganik dengan plastisitas tinggi (USCS) atau kelompok A-7-5 (32) (AASHTO) yaitu jenis tanah lanau atau lempung yang tidak tepat dijadikan sebagai tanah dasar (subgrade) jalan raya.

2. Hasil uji sifat fisis tanah yang terdiri dari uji saringan, uji specific gravity, uji batas atterberg, menunjukkan bahwa semakin tinggi persentase abu sabut kelapa dan 6\% kapur, dapat meningkatkan nilai batas susut, batas plastis, dan menurunnya, indeks 
plastisitas, batas cair, sedangkan nilai lolos sarinhgan 200 cenderung konstan, hasil uji sifat mekanis tanah menunjukkan bahwa semakin meningkat persentase abu sabut kelapa dan $6 \%$ kapur dalam tanah menunjukkan nilai pengembangan dan tekanan pengembangan menurun, sedangkan nilai kepadatan meningkat pada saat pencampuran $6 \%$ abu sabut kelapa dan $6 \%$ kapur, seiring dengan peningkatan abu sabut kelapa nilai kepadatannya menurun.

\section{Saran}

1. Untuk penelitian selanjutnya sebaiknya pengujian dilakukan beberapa kali supaya didapatkan data yang lebih baik.

2. Agar diperoleh hasil yang baik, maka penulis menyarankan sebelum melaksanakan penelitian, sebaiknya tanah sebagai sampel diuji langsung di lokasi pengambilan untuk memastikan tanah itu benar-benar bermasalah.

\section{DAFTAR PUSTAKA}

Ariyani, N. dan Nugroho, AC, 2017. Pengaruh kapur dan Abu Sekam Padi pada Nilai CBR Laboratorium Tanah Tras dari Dusun Seropan Untuk Stabilitas Subgrade Timbunan. Majalah Ilmiah Ukrim Edisi 1. 1-6, 2017

Braja M, 1998. Mekanika Tanah (PrinsipPrinsip Rekayasa Geoteknis) Jilid1, Erlangga

Desmi A, 2017. Pengaruh Campuran Abu Sabut Kelapa dengan Tanah Lempung terhadap Nilai CBR Terendam (Soaked) dan CBR Tidak Terendam. Teras Jurnal Vol. 7, No. 1,2017

Gunarti ASS, 2014. Daya Dukung Tanah Lempung yang Distabilisasi dengan Spent Catalyst RCC 15 dan Kapur. Jurnal Bentang Vol. 2 No. 1, 2014.
Haras M, 2017. Pengaruh Penambahan Kapur Terhadap Kuat Geser Tanah Lempung. Tekno Vol. 15, 2017

Herman, Sari, PO, "Pengaruh Abu Limbah Kertas terhadap Kembang Susut Tanah Lempung”, Jurnal Teknik Sipil ITP. Vol. 5 No. 1, Januari 2018

Indahyani T, 2011, Pemenfaatan Limbah Sabut Kelapa pada Perencanaan Interior dan Furniture yang Berdampak pada Pemberdayaan Masyarakat Miskin, Jakarta. Vol. 2, 2071.

Muntohar AS, 2016. Desain Nilai CBR Tanah Dasar Jalan dengan Perbaikan Kapur dan Abu Sekam Padi. ISSN : 2459-9727.

Safriani M, 2016. Analisa Pengaruh Penggunaan Abu Sabut Kelapa sebagai filler pada Campuran Aspal Retona Plend. Vol. 2 No. 2, 2016

Trikarlina E, dkk, 2017. Pemanfaatan Abu Sabut Kelapa (Cocos Nucifera) dan Pengaruh Penambahan Sikacik pada Pembuatan Batako. Vol. 6 No. $1,2017$.

Hardiyatmo, H.C. 2012. Mekanika Tanah I Edisi Ke Enam. Yogyakarta: Gadjah Mada University Press. 